\title{
Makna Kematian pada Wanita Lanjut Usia yang Melajang
}

\author{
Fahmi Mahmudayati Pratiwi, Irfan Fahmi, Anwar Supenawinata \\ UIN Sunan Gunung Djati, Jl. A.H. Nasution No. 105, Bandung \\ e-mail:irfan.fahmi@uinsgd.ac.id
}

\begin{abstract}
The purpose of this study is to explore how the meaning of death for subjects who are single elderly women. For humans, death has a double meaning that can be interpreted as a positive thing if humans do good things during their lifetime and can also be interpreted as a negative thing if humans commit bad deeds during their lifetime. This study used a qualitative approach with phenomenology methods. The participant of this study was a single elderly woman. The results in this study indicate that the subject means death as a positive thing, namely by getting closer to the Creator.
\end{abstract}

Keywords: meaning of death, elderly woman, single woman

\begin{abstract}
Abstrak
Tujuan dari penelitian ini yaitu untuk mengetahui bagaimana makna kematian bagi subjek yang merupakan wanita lansia yang melajang. Bagi manusia kematian memiliki makna ganda yaitu dapat dimaknai sebagai hal yang positif jika manusia melakukan hal yang baik semasa hidupnya dan dapat pula dimaknai sebagai hal yang negatif jika manusia melakukan perbuatan buruk semasa hidupnya. Penelitian ini menggunakan pendekatan kualitatif dengan metode fenomenologi. Subjek penelitian ini adalah seorang wanita lanjut usia yang melajang. Hasil dalam penelitian ini menunjukkan bahwa subjek memaknai kematian sebagai hal yang positif yaitu dengan lebih mendekatkan diri kepada Sang Pencipta.
\end{abstract}

Kata kunci: makna kematian, wanita lansia, wanita lajang

\section{Pendahuluan}

Teori personal meaning of death menjelaskan bahwa manusia tidak dapat menghindari fakta bahwa kematian yang akan datang pada setiap manusia. Dalam teori personal meaning of death menjelaskan bahwa kematian memiliki makna ganda bagi manusia. Pertama, jika kematian dimaknai sebagai suatu hal yang positif maka manusia akan melakukan banyak hal yang baik seperti berbenah diri, mendekatkan diri pada Tuhan. Namun, berbeda halnya jika manusia memaknai kematian sebagai suatu hal yang negatif maka manusia akan memunculkan gejolak kecemasan ketika mengingat kematian dan melakukan hal yang cenderung negatif (Cicirelli, 1998 dalam Putra, Arifin, \& Hermawati, 2016).

Penelitian yang dilakukan oleh Cicirelli (2001) menemukan bahwa makna kematian pada setiap individu dapat berubah-ubah mengikuti tahapan perkembangan manusia itu sendiri. Karena seiring dengan berkembangnya manusia maka ia akan menemukan pengalaman yang lebih banyak sehingga manusia dapat memaknai arti kematian sebagai suatu hal yang negatif maupun positif ketika manusia mulai beranjak dewasa.

Penelitian ini melibatkan satu orang subjek yang merupakan wanita dewasa akhir dan melajang, subjek lebih memilih untuk hidup sendiri dan telah menyiapkan segala hal mengenai kematiannya kelak, salah satunya dengan memesan lahan untuk kematiannya nanti dan membuat surat wasiat yang ditujukan untuk keponakan dan sanak saudaranya.

Fokus subjek saat ini adalah lebih memerdalam pengetahuan mengenai agama karena di masa mudanya ia jauh dari agama bahkan tidak mengetahui mengenai agama sehingga saat ini di usia tuanya ia ingin memperbaiki kesalahan yang telah 
diperbuat di masa mudanya. Setelah ia mulai mempelajari mengenai agama ia memaknai suatu kematian sebagai hal baik yang dapat mendorongnya untuk lebih giat dalam beribadah dan melakukan hal positif lainnya.

\section{Kematian}

Kematian merupakan ketiadaan hidup atau antonim dari hidup. Manusia dalam hidupnya mengalami dua kali masa kematian. Kematian pertama dialami oleh manusia sebelum kelahirannya. Kematian kedua manusia ialah saat manusia menghembuskan nafas terakhirnya di dunia. Setelah itu manusia akan mengalami kehidupan yang kekal di akhirat (Shihab, 2001).

Kematian tidaklah dipandang sebagai akhir keberadaan seseorang meskipun tubuh telah tiada namun jiwa diyakini masih terus hidup (Santrock, 2011). Terdapat beberapa tahap menjelang kematian menurut Kubler-Ross (1969) dalam Santrock (2011) membagi perilaku dan pikiran dari orang yang mendekati ajal ke dalam lima tahap, yaitu penolakan dan isolasi, kemarahan, tawar-menawar, depresi, dan penerimaan.

\section{Makna Kematian}

Makna kematian bagi seseorang dapat berubah seiring dengan perubahan usia manusia. Karena seiring rentang kehidupan manusia akan menemukan pengalamanpengalaman dalam kehidupannya. Dari situlah manusia mulai dapat memaknai arti kematian bagi dirinya, ketika manusia melihat sebuah kematian manusia mulai mencari tahu bagaimana kematian dapat terjadi dan mulai memikirkan apa yang akan terjadi setelah kematian tersebut (Cicirelli, 2001).

Berbeda dengan teori manajemen teror (terror management theory) yang membahas bahwa kematian merupakan suatu tindakan pengantisipasian manusia ketika ia mengingat suatu kematian. Teori manajemen teror menjelaskan bahwa kematian merupakan suatu hal yang tidak dapat dihindari namun arti kematian sangat dipengaruhi oleh self esteem dan keyakinan manusia. Self esteem merupakan suatu pendorong manusia untuk yakin akan kepercayaan yang dianutnya. Aspek lainnya yang dapat memengaruhi kematian manusia dalam teori manajemen teror (terror management theory) ialah pandangan budaya, dari pandangan budaya yang dianut maka dapat membedakan arti kematian bagi diri seseorang (Goldenberg, Pyszczynski, Greenberg, Solomon, Kluck, \& Cornwell, 2001).

\section{Aspek Makna Kematian}

Makna kematian bagi tiap manusia dapat berbeda. Ketika manusia mulai beranjak dewasa maka manusia mulai memiliki tujuan dalam hidupnya dan dari hal itulah manusia mulai dapat memaknai kematiannya (Cicirelli, 2001).

Kematian sebagai motivasi (motivation). Kematian dapat mendorong manusia untuk memperjelas tujuan hidup manusia. Ketika manusia melihat kematian orang lain maka ia sadar bahwa kehidupan saat ini hanyalah sementara sehingga manusia perlahan mulai membuat dirinya melaku-kan sesuatu yang mengarah kepada hal negatif maupun positif.

Kematian sebagai kehidupan baru (afterlife). Kematian dimaknai sebagai penutup kehidupan di dunia dan awal kehidupan baru di alam yang lain. Afterlife merupakan kematian dimaknai sebagai awal kehidupan yang baru bagi manusia. Kematian juga dapat dimaknai dengan berpisahnya manusia dengan orang-orang yang disayangi. Sehingga ketika manusia mengingat mengenai kematian maka manusia akan berusaha melakukan segala hal dengan orang-orang yang disayangi. Lain halnya ketika manusia memaknai kematian sebagai gerbang pertemuan dengan orang-orang yang disayangi namun telah lebih dulu meninggalkan dunia (Cicirelli, 2001).

Kematian sebagai warisan (legacy). Harta merupakan hal yang terkadang menjadi sesuatu yang penting sehingga 
ketika manusia mulai memaknai sebuah kematian sebagai suatu pemusnahan segala hal maka manusia mulai berpikir untuk meninggalkan suatu hal yang dapat menjadi suatu manfaat bagi keturunannya. Manusia juga melakukan hal ini yaitu meninggalkan warisan atau hartanya untuk keturunannya selain ingin membahagiakan keturunannya tujuan lain yaitu agar manusia dapat selalu dikenang walaupun setelah kematiannya.

\section{Kematian sebagai kepunahan} (extinction). Kematian dimaknai oleh manusia sebagai suatu kepunahan. Kepunahan memiliki arti hilangnya segala hal yang dimiliki manusia di dunia. Kematian juga dimaknai oleh manusia sebagai suatu ganjaran atau hukuman bagi manusia dari perbuatannya selama masa hidupnya. Kematian juga dimaknai sebagai rasa kehilangan bagi manusia. Kehilangan hal yang disukai dan memusnahkan harapan dan cita-cita seseorang selama di dunia (Cicirelli, 2001).

\section{Faktor Makna Kematian}

Faktor usia. Manusia mulai dapat memaknai kematian dalam dirinya ketika ia memasuki masa remaja. Makna kematian berubah seiring rentang kehidupan manusia karena selama rentang kehidupan manusia akan banyak mendapatkan pengalaman dalam hidupnya. Manusia yang telah memasuki usia lanjut akan merasakan takut akan kematian dibanding manusia pada usia remaja (Neimeyer \& Moore, 1989).

Faktor gender. Gender dapat membedakan makna kematian bagi individu. Namun makna kematian bagi pria maupun wanita cenderung berbeda jika pria di masa tuanya ia mulai memikirkan kematian anak-anaknya dan kematian teman sebayanya. Berbeda dengan wanita selain memikirkan akan kematiannya wanita juga lebih memikirkan kematian suaminya. Wanita lebih cenderung memikirkan mengenai kematian lebih banyak dibanding pria (Hurlock, 1998).

Faktor pengalaman. Dari pengalaman yang telah dilaluinya manusia akan dapat memaknai kematian dan dapat menjadikan hal yang positif maupun negatif. Atau juga manusia dapat memaknai kematian sebagai suatu kepunahan (extinction) atau hal lainnya (Cicirelli, 2001).

Faktor sosiokultural. Sosiokultural merupakan hal yang sangat memengaruhi perilaku maupun cara berpikir manusia. Makna kematian dapat diperkuat oleh faktor sosiokultural yang mana faktor ini akan membentuk pemaknaan tersendiri khususnya makna mengenai kematian dalam diri individu. Dari situasi itulah seseorang terbawa untuk memaknai kematian seperti yang lingkungannya ajarkan (Corwin, 2005).

Faktor religiusitas. Manusia membutuhkan rasa aman dan nyaman namun beberapa orang mendapatkan rasa nyaman dan aman ketika seseorang mulai meningkatkan kegiatan religius. Pengertian tentang perasaan tentram dan berkurangnya rasa takut akan kematian cenderung menyertai kepercayaan dan agama yang konservatif (Hurlock, 1998).

\section{Makna Kematian dalam Perspektif Islam}

Islam menjelaskan bahwa kematian bukanlah akhir dari segalanya dan setelah kematian terdapat kehidupan baru yang akan dijalani manusia dengan berbagai macam kenikmatan maupun kenistaan atau siksaan. Dalam Islam makna kematian mempunyai peranan besar dalam memantapkan aqidah. Tanpa adanya kematian manusia tidak akan berpikir tentang apa sesudah kematian, dan manusia tidak akan mempersiapkan diri menghadapinya (Shihab, 2001).

Al-Ghazali (2003) menjelaskan bahwa terdapat dua arti akan kematian dalam Islam karena mati menurutnya merupakan persoalan yang dahsyat sehingga jika seorang mengingat kematian akan sangat besar manfaatnya. Arti penting akan kematian menurut Al-Ghazali (2003) yaitu: (1) Benci pada dunia. Manusia terkadang lupa bahwa hidup di dunia hanya sementara sehingga terlalu mencintai kehidupan dan dunianya. Jika manusia mengingat arti akan 
kematian (mortality salience) maka manusia akan meninggalkan kenikmatan dunia dan lebih meningkatkan amalanamalan untuk bekal di akhirat sehingga benci akan kehidupan dan kenikmatan di dunia. Cara untuk mengingat akan kematian ialah dengan mendekatkan diri pada Allah Swt. dan mengingat kembali kesalahan-kesalahan yang telah diperbuat; (2) Rindu akhirat. Alquran mengarahkan manusia supaya tidak takut kepada perkaraperkara yang biasanya menimbulkan rasa takut pada manusia seperti kematian dan kemiskinan. Berkaitan dengan takut akan kematian Alquran telah menjelaskan bahwa kehidupan dunia adalah kehidupan yang fana dan kenikmatannya pun akan sirna. Sedangkan kehidupan akhirat adalah kehidupan yang kekal dan kenikmatannya pun kekal tidak akan sirna. Adapun kematian merupakan salah satu fase yang akan mengantarkan manusia dari kehidupan yang fana menuju kehidupan yang kekal (Najati, 2005).

\section{Wanita Usia Lanjut}

Berbeda halnya dengan pria lanjut usia yang akan lebih tertarik pada dunia politik, pada wanita lanjut usia mereka lebih sibuk mengurus dirinya dengan memercantik diri yaitu dengan berusaha memaksimalkan penampilan seperti gaya berpakaian, merawat diri, dan lainnya (Hurlock, 1998). Namun pada usia lanjut minat manusia akan lebih mengarah pada dirinya sendiri.

Ketika manusia khususnya wanita menginjak usia lanjut maka wanita akan sibuk dengan memikirkan kesehatan pasangan hidup dan dirinya sendiri karena pada usia lanjut merupakan waktu menghabiskan waktu dengan anak maupun cucu. Karena di usia lanjut manusia mengalami kemunduruan dalam hal fisik sehingga akan membutuhkan bantuan dari orang terdekatnya (Hurlock, 1998).

Pada umumnya masalah bagi wanita yang telah menginjak usia lanjut menurut Hurlock (1998) adalah: penyesuaian diri dengan masa menjanda; penyesuaian diri terhadap jumlah pendapatan yang berkurang karena kematian pasangan hidup; penyesuaian diri dengan gaya hidup yang berubah; dan kesempatan untuk menikah bagi wanita lanjut usia hanya sedikit, karena wanita lanjut usia tidak bisa mengatasi kese-piannya.

\section{Metode Penelitian}

Metode penelitian yang digunakan dalam penelitian ini adalah metode penelitian kualitatif yaitu fenomenologi. Fenomena yang diteliti pada penelitian ini ialah bagaimana wanita lanjut usia yang melajang memaknai kematian dalam dirinya.

\section{Subjek Penelitian}

Penelitian ini melibatkan satu orang subjek yang memiliki kekhasan yaitu wanita lanjut usia yaitu berusia 70 tahun yang melajang dan ia telah mempersiapkan segala hal mengenai kematiannya serta memaknai kematian sebagai suatu hal yang dapat mendorong dirinya untuk berubah menjadi lebih baik dan dekat dengan agama.

\section{Teknik Pengumpulan Data}

Pengumpulan data yang dilakukan berbentuk wawancara yang terdiri dari lima kali pertemuan yang masing-masing pertemuan berdurasi sekitar 3 jam. Selain teknik wawancara, dilakukan juga teknik observasi yang bersifat informal.

\section{Validitas Data}

Dalam penelitian ini peneliti melakukan triangulasi data yang merupakan salah satu strategi validitas data dalam penelitian kualitatif. Triangulasi data yang dilakukan oleh peneliti untuk menguji kredibilitas data yaitu dengan mewawancarai significant other yang merupakan teman sekaligus tetangga subjek.

\section{Teknik Analisis Data}

Teknik analisis data yang dilakukan terdiri dari 4 tahap. Tahap pertama ialah menyiapkan data untuk dianalisis dengan 
menggunakan transkrip wawancara dari data mentah yang telah diperoleh. Tahap kedua adalah membangun konsep umum. Peneliti membaca kembali keseluruhan data yang telah diperoleh lalu menganalisis kembali data yang telah diperoleh. Tahap ketiga yaitu coding berupa pemberian tanda atau kode pada data yang berkaitan dengan aspek yang dibutuhkan. Tahap terakhir yaitu interpretasi. Tahapan ini merupakan tahapan dimana peneliti melakukan interpretasi setelah melakukan coding pada informasi yang diperoleh dalam bentuk pembahasan (Sugiyono, 2013).

\section{Hasil Penelitian dan Pembahasan}

\section{Hasil Penelitian}

Subjek E merupakan wanita dewasa akhir dan melajang. Ia lebih memilih untuk hidup sendiri dan telah menyiapkan segala hal mengenai kematiannya kelak, salah satunya dengan memesan lahan untuk kematiannya nanti dan membuat surat wasiat yang ditujukan untuk keponakan dan sanak saudaranya. Saat ini subjek lebih banyak menjalin silaturahim dengan temantemannya dan meningkatkan kegiatan keagamaan di lingkungan tempat tinggalnya.

Setelah menginjak masa pensiunnya dari perusahaan $\mathrm{K}$, subjek merasa jatuh dan sedih karena keadaan yang berbeda ketika ia masih bekerja dengan kehidupan sebagai pensiunan. Subjek sempat berkonsultasi dengan psikolog untuk mengatasi keadaannya setelah pensiun. Setelah melakukan konsultasi dengan psikolog, subjek disarankan untuk melakukan hal yang disenangi dan lebih mendekatkan diri pada kegiatan keagamaan. Subjek mencoba untuk mulai membuka kantor notaris di rumahnya untuk mengisi waktu luangnya. Selain itu, subjek juga mengikuti kegiatan keagamaan seperti mendengarkan ceramah, belajar mengaji, dan lainnya. Seiring dengan berjalannya waktu subjek mulai merasakan nyaman ketika ia mengikuti kegiatan keagamaan dan mulai menyadari bahwa di masa lalunya subjek sangatlah kurang memahami mengenai hal agama. Saat ini subjek sudah pensiun dan tinggal di rumah miliknya sendiri serta rutin mengikuti kegiatan perkumpulan notaris seminggu sekali.

\section{Aspek Makna Kematian}

Motivasi. Motivasi merupakan bagaimana subjek memaknai suatu kematian sebagai dorongan dalam hidupnya untuk menjadikan dirinya lebih baik dan memperjelas tujuan hidupnya. Selain itu kematian dimaknai sebagai suatu motivasi juga dapat menyiapkan diri bagi $\mathrm{E}$ untuk menghadapi kematian.

Mengingat kematian dapat menjadikan subjek menjadi lebih baik, selain itu kematian dapat menjadi suatu dorongan bagi dirinya untuk lebih mendekatkan diri pada Allah Swt. Subjek memandang bahwa kematian merupakan suatu hal yang positif dan dapat menjadikan evaluasi bagi dirinya.

"Kematian itu bertemu Allah ya, makanya saya berusaha dan berpikir kematian itu baik ya, itu karena akan bertemu dengan Maha Pencipta" (PMOD.A.2a.).

"Mengingat mati itu supaya tingkat keimanan kita itu lebih baik lagi kemudian hidup itu harus baik ya kepada orang lain, amal ibadah kita itu harus terus buat orang lain, walaupun masih belum sempurna ya ibadah saya" (PMOD.A.1a \& PMOD.A. $2 a)$.

"Kalau ingat usia saya ingat mati saya jadi ngomong sama diri saya sendiri apa bekal kamu udah cukup buat dibawa nanti kalau meninggal? apa aja yang udah kamu lakuin selama di dunia? saya suka bertanyatanya gitu" (PMOD.A.3a).

"Ya itu karena khawatir ya ada rasa takut jika saya tidak diterima atau takut neraka intinya mah itu, jadi lebih fokus gitu" (PMOD.A.3a).

Saat ini subjek hanya fokus untuk meningkatkan kegiatan keagamaan karena menurutnya salah satu bekal untuk dibawa ketika meninggal adalah ibadah yang diamalkan selama di dunia. Karena subjek merasa di waktu muda tidak mengetahui mengenai agama sehingga ia merasa menyesal di usia tuanya saat ini. 
"Saya suka berpikir mau kemana saya sekarang ini. Jika dulu saya hanya mikirin uang, uang, uang, tapi sekarang sudah tidak mikirin kaya gitu lagi" (PMOD.A.2a).

"Kita memang mencari tabungan di akhirat, memang mencari tabungan di akhirat itu caranya macem-macem dengan cara kita ke masjid mengaji” (PMOD. A.3a).

Afterlife. Subjek yakin bahwa setelah manusia meninggal manusia akan dihidupkan kembali. Dari situasi itulah awal kehidupan baru dimulai. Mengingat kematian bagi subjek membuat hidupnya lebih fokus khususnya dalam hal beribadah.

"Tetapi terkadang saya suka tidak fokus ketika shalat tetapi kan saya mencoba sedikit-sedikit karena ketika meninggal nanti yang dihisab pertama kali itu kan shalat ibu. Jadi ibu harus mencoba lebih khusyuk ketika shalat karena ibu menganggap ibu sedang berdialog pada Allah" (PMOD.B.2b.).

"Enggak ya enggak hilang, karena kan disana kita hidup kembali" (PMOD.B.2b).

Bagi subjek, kehidupan setelah kematian merupakan awal kehidupan baru yang ditentukan oleh sikap dan perbuatan manusia selama di dunia. Kehidupan setelah kematian akan dirasakan baik jika manusia melakukan hal yang baik selama di dunia begitu juga sebaliknya.

"Itu kan awal dari kehidupan ya makanya itu dengan kematian itu kita harus balik gitu kematian itu kan awal hidup yang akan datang sehingga untuk menjemput kematian atau untuk menjalani kematian itu kita harus baik gitu ya harus berbuat baik sesuai agama kita aja, tapi untuk kehidupan ini. Nah, kehidupan yang akan datang itu tergantung dari hidup yang sekarang ini makanya ini harus baik karena itu awal untuk menginjak ke kehidupan yang akan datang" (PMOD.B.1b).

"Di bayangan saya, saya harus masuk surga. Di bayangan saya hidup di sana itu nanti senang gitu segala macam ada, walaupun dengan kekurangan saya seperti ini. Karena Allah Maha Mengetahui kan telah menetapkan ya kamu kaya begini, kamu kaya begini. Rizki, jodoh, bagja, cilaka itu kan sudah diatur oleh Allah" (PMOD.B. 1b).

"Ya sedih banget ngeliat temen-temen saya yang sudah mendahului itu karena sudah tidak bisa komunikasi, kadang juga kangen dengan candaan temen-temen. Kan makanya harus terus menyiapkan bekal karena saya juga gak tau saya di menit mana di hari apa ya saya meninggal nanti" (PMOD.B.2b).

Warisan. Kematian dimaknai sebagai suatu kehilangan akan hal yang dimiliki selama di dunia. Selain itu manusia berlomba-lomba meninggalkan harta dan perbuatan baik selama hidupnya yang bertujuan agar selalu dikenang setelah meninggal.

Sampai saat ini subjek sudah membagi harta yang akan dibagi pada keponakan yang diasuhnya sejak kecil. Walaupun subjek belum memahami bagaimana pembagian warisan yang baik karena subjek hidup sendiri maka ia membagi harta yang dimiliknya pada keponakan ataupun saudara terdekat jika meninggal nanti.

"Saya itu masih gambling ya hukum antara hukum Islam atau hukum Negara ya untuk saudara-saudara itu ya harta yang harus dibagi" (PMOD.C.2c).

"Itu ya yang saya pikirkan tapi kalau harta warisan saya ngebaginya itu saya masih gambling ya karena saya sendiri jadi saya masih bingung ngebaginya gimana. Tapi kalau buat adik-adik saya itu sudah ya saya bagi" (PMOD.C.2c).

"Kalau ya amal ibadah kita di dunia sesuai dengan yang dianjurkan Alquran ya. Itu setau saya ya misalnya melakukan hal yang baik gitu ya. Misalnya saya nyapuin solokan orang, bersihin halaman orang" (PMOD.C.1c).

"Kan kalau untuk saudara mah sama aja ya kaya saya menyekolahkan, membayar biaya kuliah sampai selesai, makan, pakaian ya kan itu sudah sama aja, masuk ke ITB masuk ke Padjadjaran kan itu ya" (PMOD.C.2c). 
"Dari situ ya saya bisa jadi bermanfaat bagi orang lain walaupun saya sudah tua. Itulah hidup saya sekarang dinikmati, disyukuri. Terimakasih Ya Allah masih bisa bersih-bersih rumah sendiri tanpa minta bantuan orang lain" (PMOD.C.1c).

"Walaupun tapi gini kan kalau sudah meninggal itu kan orang itu memang terus terkenang tapi kan yang buruknya suka terkenang ya. Tapi kalau saya inginnya ya keburukan saya terhapus ya, bukan terhapus ya tapi saya sebisa saya buat yang bisa terkenang itu yang baiknya saya ya kaya misalnya di keluarga gitu ya. Jadi pokoknya harus yang baik ya supaya harum, eh bukan harum ya apa ya, gini misalnya meninggal tapi terkadang orang jarang ya ingat yang jeleknya sering itu mengingat hal yang baik ya" (PMOD. C. $1 c)$.

Extinction. Kematian dimaknai sebagai suatu konsekuensi yang harus dihadapi oleh setiap manusia atas segala perbuatannya selama hidupnya. Kematian bagi subjek memusnahkan raga manusia dan segala hal yang ada di dunia tetapi di lain hal ketika manusia mati maka hal-hal baik maupun buruk akan dibawa dan hal itu yang menjadikan bekal manusia. Selain membagi harta untuk saudara terdekat, bagi subjek warisan juga dapat berupa membiayai pendidikan keponakankeponakannya hing-ga tuntas. Baginya hal itu sama saja seperti membagi harta yang dimilikinya.

"Saya mati berarti berakhir segalanya. Kalau mati kan berakhir segala-galanya kan. Makanya saya lebih baik lagi saya harus terarah hidup lagi hidup saya" (PMOD.D.3d).

"Iya kematian itu perpisahan ya. Berpisah dengan orang yang hidup ya. Tapi di lain pihak akan bertemu dengan Allah" (PMOD.D.1d).

"Enggak ya harapan manusia enggak hilang, karena kan di sana kita hidup kembali" (PMOD.D.3d).

"Kematian itu bukan hukuman ya. Itu mah sudah dari sananya bahwa semua makhluk hidup sudah pasti diambil kembali sama yang punya. Kalau hukuman kan mungkin hanya apa ya kaya orang tua menghukum anaknya. Karena kan Allah Maha Kasih Masa Sayang ya jadi itu bukan hukuman" (PMOD.D.2d).

Bagi subjek jika semasa di dunia manusia berbuat baik maka manusia akan mendapatkan ganjaran yang setimpal setelah kematiannya namun sebaliknya jika manusia hanya berbuat hal buruk selama masa hidupnya maka akan mendapatkan hukuman di kehidupan setelah kematian.

"Kematian hanya salah satu jalan untuk bertemu Allah. Kalau ya kalau kita baik di dunia bener kalau yang dicantumkan dalam Alquran dan sunnah Rasul itu kita laksanakan” (PMOD.D.2d).

\section{Makna Kematian Bagi Subjek}

Berdasarkan hasil wawancara yang telah dilakukan oleh peneliti, bagi subjek dengan statusnya yang lajang dapat membuat dirinya lebih fokus dalam menjalani ibadah yang bertujuan untuk menambah bekal menghadapi kematian yang tidak dapat diketahui kapan akan datang padanya. Hidup sendirian dapat membuat dirinya fokus memikirkan apa yang ingin dilakukannya. Saat ini fokus subjek hanyalah melakukan hal yang dapat membantu lingkungan sekitarnya atau dapat bermanfaat bagi orang lain. Karena subjek merasa di usianya yang lanjut saat ini sudah tidak mampu lagi melakukan aktivitas seperti sebelum masa pensiunnya sehingga subjek hanya ingin bermanfaat bagi lingkungan sekitarnya. Bekal menghadapi kematian bagi subjek tidak hanya mengaji dan shalat tetapi juga membantu orang lain. Selain itu, subjek merasakan ketenangan ketika ia dapat membantu dan bermanfaat bagi orang lain.

Kematian bagi subjek dapat mengubah tingkah lakunya seiring dengan bertambahnya usia maka subjek mulai dapat memahami kematian sebagai suatu evaluasi diri baginya. Karena di masa mudanya subjek merasa tidak mengenal mengenai 
agama maka di usianya yang lanjut saat ini subjek mulai memperbaiki diri yaitu dengan mendekatkan diri pada Allah Swt., diantaranya mengikuti pengajian baik di lingkungan rumahnya, maupun di luar lingkungan rumahnya. Baginya dengan mendekatkan diri pada Allah Swt. menjadikan dirinya tenang ketika mengingat mengenai kematian yang dirasakan semakin dekat.

Terkadang subjek merasakan kurang fokus dalam beribadah disebabkan suatu masalah kecil sehingga terkadang membuat subjek menunda kewajibannya dalam beribadah tetapi ketika subjek mulai mengingat bahwa kematian dapat datang kapan saja subjek mulai fokus kembali dalam beribadah. Subjek juga memaknai kematian merupakan suatu awal kehidupan baru yaitu setiap manusia yang mengalami kematian maka mereka akan hidup kembali di dunia yang indah.

Subjek terkadang merasa tidak tenang jika harta yang dimilikinya seperti uang dan property yang ia miliki saat ini dapat membuat kericuhan diantara sanak saudaranya ketika ia meninggal nanti. subjek memaknai kematian sebagai suatu jalan atau suatu cara untuk bertemu Allah Swt. Ketika merasakan takut saat mengingat kematian subjek akan membayangkan bahwa kehidupan setelah kematian merupakan suatu kehidupan yang indah sehingga ketakutan tersebut sedikit demi sedikit menghilang. Sehingga makna kematian bagi subjek bukanlah suatu hukuman atau pemusnahan. Istilah pemusnahan ketika manusia meninggal bagi subjek merupakan hal yang benar, tetapi bukan berarti musnah segala hal yang telah dilakukan seseorang ketika di dunia. Bagi subjek kematian hanyalah memusnahkan hal yang dimiliki di dunia seperti harta misalnya tetapi amalan yang telah dilakukan tidaklah musnah ketika seseorang mengalami kematian.

\section{Pembahasan}

Berdasarkan hasil wawancara yang telah dilakukan oleh peneliti, makna kematian baginya yang hidup sendiri di usianya yang telah lanjut merupakan suatu dorongan bagi dirinya untuk dapat menjalani hidup lebih baik. Bagi subjek E dengan statusnya yang lajang dapat membuat dirinya lebih fokus dalam menjalani ibadah yang tujuannya untuk bekal setelah kematian datang padanya. Saat ini fokus E hanyalah melakukan hal yang dapat membantu lingkungan sekitarnya atau dapat bermanfaat bagi orang lain. Karena, E merasa di usianya yang lanjut saat ini sudah tidak mampu lagi melakukan aktivitas seperti sebelum masa pensiunnya sehingga $\mathrm{E}$ hanya ingin bermanfaat bagi lingkungan sekitarnya.

Kematian bagi $\mathrm{E}$ dapat mengubah tingkah lakunya seiring dengan bertambahnya usia maka $\mathrm{E}$ mulai dapat memahami kematian sebagai suatu evaluasi diri baginya. Karena di masa mudanya $\mathrm{E}$ merasa tidak mengenal mengenai agama maka di usianya yang lanjut saat ini $E$ mulai memperbaiki diri yaitu dengan mendekatkan diri pada Allah Swt. diantaranya mengikuti pengajian di lingkungan rumahnya, maupun pengajian di luar lingkungan rumahnya. Baginya dengan mendekatkan diri pada Allah Swt. menjadikan dirinya tenang ketika mengingat mengenai kematian yang dirasakan semakin dekat.

Terkadang E merasakan kurang fokus dalam beribadah disebabkan suatu masalah kecil sehingga terkadang membuat $E$ menunda kewajibannya dalam beribadah tetapi ketika $\mathrm{E}$ mulai mengingat bahwa kematian dapat datang kapan saja E mulai fokus kembali dalam beribadah. $\mathrm{E}$ juga memaknai kematian merupakan suatu awal kehidupan baru yaitu setiap manusia yang mengalami kematian maka mereka akan hidup kembali di dunia yang indah. Tetapi sebelum manusia memulai kehidupan yang baru bagi $\mathrm{E}$ harus melalui suatu kematian terlebih dahulu. Baginya kehidupan setelah kematian dapat dirasakan indah jika seseorang berbuat baik dan mengamalkan segala perintah Allah Swt. dengan baik 
namun sebaliknya jika seseorang tidak melaksanakan perintah agama maka seseorang akan merasakan kehidupan yang buruk setelah kematian.

E terkadang merasa tidak tenang harta yang dimilikinya seperti uang dan rumah yang dimilikinya saat ini dapat membuat kericuhan diantara sanak saudaranya. Dari situasi itulah E sebelum menginjak masa pensiunnya mulai membuat surat wasiat yang berisi pembagian harta yang dimilikinya pada saudara terdekat dan keponakannya. Bagi $\mathrm{E}$ dengan menulis wasiat dan membagi harta yang dimiliki pada saudaranya dapat menjadikan ketenangan ketika meninggal nanti.

E memaknai kematian sebagai suatu jalan atau suatu cara untuk bertemu Allah Swt. Ketika merasakan takut saat mengingat kematian, E akan membayangkan bahwa kehidupan setelah kematian merupakan suatu kehidupan yang indah sehingga ketakutan tersebut sedikit demi sedikit menghilang. Sehingga makna kematian bagi $\mathrm{E}$ bukanlah suatu hukuman atau pemusnahan. Istilah pemusnahan ketika manusia meninggal bagi $\mathrm{E}$ merupakan hal yang benar, tetapi bukan berarti musnah segala hal yang telah dilakukan seseorang ketika di dunia. Bagi E kematian hanyalah memusnahkan hal yang dimiliki di dunia seperti harta misalnya tetapi amalan yang telah dilakukan tidaklah musnah ketika seseorang mengalami kematian.

Dari hasil pemaparan E, sesuai dengan teori Cicirelli (2001) bahwa makna kematian bagi individu memiliki empat aspek yaitu: (a) motivation: kematian dimaknai sebagai suatu dorongan yang membuat manusia bertindak lebih baik untuk kehidupan dan kematiannya; (b) afterlife: kematian dimaknai sebagai awal kehidupan baru bagi manusia; (c) legacy: kematian dimaknai dapat meninggalkan hal yang dapat dikenang; (d) extinction: kematian dimaknai sebagai suatu pemusnahan ruh dan konsekuensi dari segala perbuatan manusia. Dari keempat aspek makna kematian E lebih dominan pada motivation yaitu memaknai kematian sebagai dorongan untuk hidup lebih baik.

Kematian memiliki makna ganda menurut Cicirelli (2001) yaitu: (a) positif: manusia akan menganggap kematian sebagai suatu hal yang baik bagi dirinya jika selama hidupnya melakukan hal yang baik; (b) negative: manusia akan menganggap kematian merupakan hal yang menakutkan karena telah melakukan banyak hal buruk semasa hidupnya. Dari pemaparan E memaknai kematian sebagai hal yang positif walaupun di masa mudanya E tidak mengenal agama tetapi saat ini $\mathrm{E}$ sangat giat dalam kegiatan keagamaan yang bertujuan untuk membayar perbuatan negatifnya di masa muda.

Faktor yang membedakan makna kematian bagi setiap individu menurut Neimeyer dan Moore dalam Cicirelli (2001) yaitu: (a) faktor gender; (b) faktor pengalaman; (c) faktor sosiokultural; (d) faktor religiusitas; (e) faktor usia. Dari hasil pemaparan $\mathrm{E}$ faktor yang membuat dirinya memaknai kematian sebagai suatu motivasi maupun suatu hal yang positif yaitu di usianya yang lanjut ia merasakan ketenangan ketika mendekatkan diri pada Allah Swt. serta lingkungan yang membawanya untuk lebih rajin dalam mengikuti kegiatan keagamaan di lingkungan rumahnya.

\section{Simpulan dan Saran}

\section{Simpulan}

Berdasarkan pembahasan sebelumnya dapat diambil simpulan dari penelitian ini bahwa: berdasarkan keempat aspek personal meaning of death subjek memaknai kematian sebagai dua aspek yaitu motivation dengan subjek memaknai kematian sebagai suatu hal yang dapat menjadikan dirinya lebih tekun beribadah dan legacy yaitu subjek telah membagi seluruh harta yang dimilikinya untuk sanak saudara terdekatnya secara sah di hadapan notaris yang bertujuan agar ketika ia menghadapi kematiannya nanti harta yang 
dimilikinya tidak menjadikan perpecahan antara sanak saudaranya.

Namun dari dua aspek makna kematian subjek lebih dominan pada aspek motivation yaitu dimana subjek memaknai kematian sebagai suatu hal yang positif dan menjadikan kematian sebagai suatu dorongan atau motivasi bagi dirinya untuk dapat lebih dekat pada Allah Swt. Bagi subjek kematian merupakan cara untuk bertemu Allah Swt. Baginya selain mendekatkan diri pada Allah Swt. dengan berbuat kebaikan secara ikhlas dapat menjadikan bekal untuk kematiannya. Baginya kematian dapat dimaknai secara positif jika seseorang melakukan perintah agama dengan baik tetapi sebaliknya kematian dapat dimaknai sebagai hal yang negatif jika seseorang tidak mentaati perintah agamanya.

Dari hasil pemaparan subjek, sesuai dengan teori yang telah dijelaskan bahwa makna kematian bagi individu memiliki empat aspek yaitu: (a) motivation: kematian dimaknai sebagai suatu dorongan yang membuat manusia bertindak lebih baik untuk kehidupan dan kematiannya; (b) afterlife: kematian dimaknai sebagai awal kehidupan baru bagi manusia; (c) legacy: kematian dimaknai dapat meninggalkan hal yang dapat dikenang; (d) extinction: kematian dimaknai sebagai suatu pemusnahan ruh dan konsekuensi dari segala perbuatan manusia.

Bagi subjek di masa mudanya tidak mengingat Allah dan tidak mengetahui mengenai agama karena baginya lingkungan yang membawanya jauh dari agama. Seiring dengan berjalannya waktu subjek yang telah menginjak masa pensiun lalu berpindah tempat tinggal dengan begitu ia bertemu dengan orang-orang baru dan lingkungan baru dari situasi itulah yang mulai membawa subjek mengenal agama dan memutuskan untuk lebih mendekatkan diri pada Allah sehingga subjek mulai menyadari bahwa kehidupan saat ini hanyalah sementara. Bagi subjek saat ini adalah waktu untuk mempersiapkan diri dan memperbanyak bekal untuk menghadapi kematian.

\section{Saran}

Subjek diharapkan dapat belajar untuk evaluasi diri dan selalu mengingat bahwa kehidupan dunia hanyalah sementara. Selagi masih diberi kesempatan lebih baik jika meningkatkan ibadah dan menolong sesama yang membutuhkan. Selalu mengingat bahwa kematian dapat datang pada siapa saja tidak memandang usia dan waktu.

Untuk penelitian selanjutnya, dapat melakukan metode yang berbeda selain metode kualitatif jika ingin mengembangkan penelitian mengenai makna kematian pada wanita lanjut usia yang melajang.

\section{Daftar Pustaka}

Al-Ghazali, A. (2003). 40 dasar agama menurut Hujjah Al-Islam, Yogyakarta: Futuh Printika.

Cicirelli, V. G. (2001). Personal meanings of death in young adults and older adults in relation to their fears of death. Death Studies, 25(8), 663-683.

Corwin, H. J. (2005). The fear of death and fear of dying: Possible barriers to altruistic behavior. Michigan: Eastern Michigan University.

Goldenberg, J. L., Pyszczynski, T., Greenberg, J., Solomon, S., Kluck, B., \& Cornwell, R. (2001). I am not an animal: Mortality salience, disgust, and the denial of human creatureliness. Journal of Experimental Psychology: General, 130(3), 427-435. doi.org/10.1037/0096-3445.130.3.427

Hurlock, E. B., (1998). Psikologi perkembangan suatu perkembangan sepanjang rentang kehidupan. Jakarta: Erlangga.

Najati, U. (2005). Psikologi dalam Alquran. Bandung: CV. Pustaka Setia.

Neimeyer, R. A., \& Moore, M. K. (1989). Assessing personal meanings of death: Empirical refinements in the threat index. Death Studies, 13(3), 227-245. 
doi.org/10.1080/07481188908252301

Putra, B. S., Arifin, B. S., \& Hermawati, N. (2016). Mortality salience dengan kebahagian pada masa dewasa awal. Jurnal Ilmiah Penelitian Psikologi, 04(01), 100-112.

Santrock, J. W. (2011). Life span development (terjemahan) jilid 2 . Jakarta: Erlangga.

Shihab, Q. (2001). Perjalanan mеnuju keabadian, kematian surga, dan ayatayat tahlil. Jakarta: Lentera Hati.

Shihab, Q. (1996). Wawasan Alquran. Bandung: Mizan Media Utama.

Sugiyono. (2013). Metode penelitian kuantitatif dan kualitatif. Bandung: Alfabeta. 
Psympathic, Jurnal Ilmiah Psikologi Desember 2018, Vol. 5, No. 2, Hal. : 241-252 